\title{
DIVERSIFIKASI PRODUK PANGAN BERBASIS AIR KELAPA
}

\author{
Ervina Mela, Mustaufik, Ali Maksum, dan Nino Godlif Tbet \\ Program Studi Ilmu dan Teknologi Pangan, Jurusan Teknologi Pertanian, \\ Fakultas Pertanian, Universitas Jenderal Soedirman \\ Email: ervina.mela@unsoed.ac.id
}

\section{ABSTRACT \\ Diserahkan: 5 September 2020 \\ Diterima: 7 Desember 2020}

Coconut water is obtained from coconuts which fruit and water are taken for direct consumption or from the by-products of coconut milk processing. Coconut water contains carbohydrates, protein (amino acids), and minerals. The processing of coconut water into products with high added value is still very limited. Therefore, this paper aims to summarize the research from literature studies, which process coconut water into various food products. Food product diversification from coconut water includes bottled coconut water, isotonic drinks, nata de coco, vinegar, antioxidant drinks, carbonated drinks, date juice, coconut yoghurt, drink yoghurt, coconut drink powder, probiotic drinks, coconut sorbet, edible film, coco cider, kefir, coconut milk, soy sauce, ginger coconut candy, coconut jelly candy, coconut cheese, and coconut jam.

Keywords: coconut water, diversification, food products

\section{PENDAHULUAN}

Air kelapa diperoleh dari buah kelapa, baik kelapa tua atau muda. Air kelapa muda memiliki kandungan gizi makro dan mikro yang relatif lengkap terdiri dari karbohidrat, protein, vitamin, dan mineral. Meskipun air kelapa hanya mengandung $0,1 \%$ protein, namun mengandung beberapa asam amino yang lebih tinggi dari yang terdapat pada susu sapi (Barlina, 2016).

Pada bidang pangan dan kesehatan, karena air kelapa mengandung elektrolit yang tinggi dan bersifat isotonis dengan adanya mineral natrium dan kalium, maka air kelapa dapat digunakan sebagai alternatif rehidrasi secara oral maupun intravena pada kondisi yang darurat (Yong et al., 2009). Bahkan karena rasanya yang manis dan segar, maka air kelapa dapat diminum dalam jumlah lebih banyak pada saat berolahraga (Yong et al., 2009) sehingga tubuh dapat terehidrasi dengan cepat (Saat et al., 2002). Selain itu, air kelapa juga berkhasiat dalam mengurangi gangguan pencernaan yang berupa mual, kembung, dan rasa tidak nyaman di perut.

Air kelapa biasa diperoleh sebagai hasil samping pengolahan kelapa parut menjadi santan, atau dari pembuatan minyak. Selain itu air kelapa, dapat juga diperoleh dari buah kelapa segar yang dijual sebagai kelapa muda. Meskipun kandungan gizi air kelapa bermanfaat bagi kesehatan, namun pengolahan air kelapa menjadi produk pangan masih sangat terbatas. Perlu upaya untuk mengembangkan air kelapa menjadi berbagai produk pangan bernilai tambah tinggi. Tulisan 
ini bertujuan untuk merangkum beberapa hasil penelitian sehubungan dengan pemanfaatan air kelapa menjadi produk pangan. Semakin beragamnya produk yang dapat dihasilkan dari air kelapa, diharapkan dapat meningkatkan nilai tambah komoditas kelapa, sehingga pendapatan petani dan industri pengolahan kelapa juga dapat meningkat.

\section{DIVERSIFIKASI PRODUK PANGAN BERBASIS AIR KELAPA}

\section{Air kelapa dalam kemasan}

Air kelapa dapat diolah menjadi minuman dalam kemasan yang higienes dan bergizi. Meski demikian air kelapa mudah rusak sehingga umur penyimpanannya pendek. Minuman kelapa kemasan merupakan minuman murni air kelapa yang dimodifikasi untuk memperpenjang umur simpan air kelapa. Pembuatan air kelapa kemasan ini menggunakan teknologi ultrafiltrasi dan ultraviolet. Secara umum penggunaan membran ultrafiltrasi digunakan untuk memisahkan mikroorganisme, molekulmolekul besar dan emulsi dalam air (Marlina, 2017).

Kailaku et al. (2016) mengolah produk minuman air kelapa melalui proses ultrafiltrasi dan ultraviolet. Air kelapa yang diproses dengan cara tersebut ternyata tidak berbeda jauh dengan air kelapa segar, dari segi rasa dan aromanya. Bahan utama yang digunakan dalam pembuatan produk ini yaitu air kelapa genjah umur 8-9 bulan. Pembuatannya adalah sebagai berikut: air kelapa disaring kemudian dilewatkan pada unit membran mikrofiltrasi, baru kemudian membran ultrafiltrasi. Setelah itu dikemas dan disimpan pada suhu $0{ }^{\circ} \mathrm{C}$.

\section{Minuman Isotonik}

Air kelapa dapat diolah menjadi minuman isotonik. Yang dimaksud dengan minuman isotik adalah minuman yang diolah sedemikian rupa untuk memperoleh tekanan osmotik yang sama dengan tekanan darah manusia. Kondisi seperti ini, menyebabkan kandungan yang terdapat pada minuman menjadi lebih mudah diserap tubuh. Oleh karena itu, minuman isotonik dikonsumsi dengan tujuan mendapatkan energi dan menggantikan ion-ion tubuh yang hilang ketika beraktivitas fisik seperti olahraga.

Sukendar et al. (2018) telah melakukan penelitian pembuatan minuman isotonik dari kelapa dengan penambahan gula dan buah belimbing wuluh yang mengandung senyawa flavonoid dan triterpenoid. Proses pembuatan minuman isotonik ini meliputi: preparasi ekstrak belimbing wuluh, preparasi air kelapa, penambahan gula ke dalam air kelapa, penambahan ekstrak belimbing wuluh, sterilisasi, dan pengemasan.

Ekstrak belimbing wuluh sebanyak 800 gram dicuci, dipotong-potong menjadi ukuran yang lebih kecil lalu dihaluskan dengan blender, kemudian disaring menggunakan saringan kasar. Dari 800gram belimbing wuluh dihasilkan 400gram ekstrak. Setelah didapatkan ekstrak belimbing tahap selanjutnya adalah preparasi air kelapa. Air kelapa diproses terlebih dahulu dengan cara 
dipisahkan dari daging buahnya kemudian disaring menggunakan penyaringan kasar secara aseptik. Setelah itu ditambahkan sebanyak 6-7\% dalam $100 \mathrm{ml}$. Selanjutnya ditambahkan ekstrak belimbing wuluh sebanyak $400 \mathrm{ml}$ dan disterilisasi. Tahap terakhir yakni pengemasan menggunakan botol plastik. Botol kemasan yg akan dipakai sebelumya disterilisasi menggunakan alkohol 95\% dan dikeringkan di laminar flow.

\section{Nata De Coco}

Nata de coco adalah sejenis jelly yang bertekstur kenyal, berwarna bening sampai putih yang diperoleh dari fermentasi bakteri Acetobacter xylinum. Acetobacter dapat membentuk nata jika ditumbuhkan pada air kelapa dengan penambahan karbon (C) dan Nitrogen $(\mathrm{N})$. Bakteri ini dapat membentuk enzim ekstra seluler yang menghasilkan selulosa berwana putih hingga transparan yang tergolong pada serat pangan. Nata yang mengandung serat pangan ini sangat baik apabila dikonsumsi. Pengolahan nata dapat berupa makanan atau minuman (dessert).

Bahan yang digunakan untuk pembuatan nata de coco yaitu air kelapa $100 \mathrm{ml}$, bibit starter sebanyak $12 \mathrm{ml}$, gula pasir 3,5 gram, urea 0,6 gram dan cuka makanan sebanyak 4 $\mathrm{ml}$, starter nata (Acetobacter xylinum) sebanyak $60 \mathrm{ml}$, urea, ZA dan yeast ekstrak sebanyak 3 gram (Hamad dan Kristiono, 2013).

Pembuatan nata de coco diawali dengan penyaringan air kelapa untuk menghilangkan kotoran yang ada, selanjutnya air kelapa direbus sampai mendidih, kemudian urea, gula dan cuka dilarutkan dalam air kelapa yang masih panas, selanjutnya air kelapa ditempatkan ke wadah fermentasi lalu ditutup. Setelah larutan dingin ditambahkan bibit starter kemudian ditutup kembali. Setelah nata terbentuk dalam beberapa hari, dilakukan pencucian dengan air mengalir untuk menghilangkan bau dari nata.

\section{Cuka}

Kata vinegar atau cuka berasal dari bahasa Perancis, vin igre yang berarti anggur asam. Cuka merupakan salah satu golongan karboksilat yang sering digunakan setiap hari sebagai pemberi rasa asam pada masakan. Ciri cuka yaitu berupa cairan bening yang tidak berwarna dengan bau yang menyengat. Cuka dapat dibuat dari buah buahan seperti apel dan anggur ataupun buah-buahan lainnya yang mengandung gula (Ndaru, 2008).

Berdasarkan penelitian Hasanuddin et al. (2012), bahan yang digunakan untuk pembuatan cuka kelapa yaitu air kelapa tua, ragi fermipan, asam asetat 35 liter, gula pasir, air, $\mathrm{NaOH}, \mathrm{NaCl}$, asam tartrat, perak nitrat $0,1 \mathrm{~N}$, vanilin alkohol, larutan floroglosinol, dan PP $1 \%$.

Sebanyak 20liter air kelapa ditambahkan gula dan dilarutkan hingga gulanya larut, didinginkan dan ditambahkan ragi, selanjutnya disaring dan dimasukan ke dalam jerigen ukuran 20 Liter dan didiamkan selama 1 minggu untuk mengalami fermentasi anaerob. Selanjutnya, disaring dan dimasukkan ke dalam fermentor yang sudah disiapkan cuka 
starter (asam asetat 10\%) sebanyak 35 liter, dan dibiarkan untuk mengalami fermentasi aerob.

\section{Minuman Antioksidan}

Antioksidan merupakan salah satu zat yang dapat mengurangi kerusakan sel akibat proses oksidasi. Mengonsumsi makanan atau minuman yang mengandung antioksidan secara teratur dapat meningkatkan imun tubuh, memperlambat penuaan, dan menghambat penyakit degeneratif (Winarsih, 2007). Minuman antioksidan kelapa merupakan minuman fungsional yang mengandung antioksidan dan isotonik bagi tubuh.

Lestario (2017) telah melakukan penelitian untuk membuat minuman antioksidan dari air kelapa dan bunga Rosella. Rosella mengandung pigmen antosianin yang berfungsi sebagai antioksidan sedangkan air kelapa mengandung gula, mineral, dan vitamin sehingga dapat menjaga keseimbangan elektrolit bagi tubuh. Menurut Lestario (2017) kandungan antosianin yang terdapat dalam ekstrak rosella cukup tinggi sebesar $8,13 \mathrm{mg} /$ $100 \mathrm{~g} \mathrm{bb}$, sehingga rosella memiliki potensi besar untuk dijadikan minuman antioksidan bersama air kelapa.

Adelia et al. (2017) dalam penelitiannya menggunakan bahan utama minuman antioksidan berupa kelopak rosella kering dan air kelapa muda. Pembuatan minuman antioksidan ini diawali dengan pembuatan ekstrak rosella. Bunga Rosella direbus menggunakan aquadest (1:3) dalam suhu $40^{\circ} \mathrm{C}$ selama 15 menit, setelah rosella diekstraksi selanjutnya, ekstrak tersebut dicampurkan dengan air kelapa dengan perbandingan 25\%:75\% dan dipasteurisasi kemudian dipanaskan pada suhu $65^{\circ} \mathrm{C}$.

\section{Minuman Berkarbonasi}

Minuman berkarbonasi atau soft drink adalah minuman yang yang mengandung gula, karbon dioksida, dan tidak mengandung alkohol. Secara umum komposisi minuman berkarbonasi meliputi air, konsentrat, bahan pemanis, pemberian rasa asam, dan pemberi aroma. Minuman berkarbonasi yang sering dikonsumsi di Indonesia adalah Fanta, Sprite, dan Coca-cola. Minuman berkarbonasi mempunyai ciri khas efek sparkle (perasaan yang menggigit di lidah pada saat diminum).

Penelitian Zulaika et al.

(2016) menunjukkan bahwa air kelapa memiliki potensi untuk dijadikan minuman berkarbonasi. Pada penelitiannya, air kelapa ditambahkan sari sirsak untuk meningkatkan nilai gizi dan cita rasa dari minuman berkarbonasi. Bahan yang digunakan untuk membuat minuman berkarbonasi yaitu yaitu air kelapa, ekstrak sirsak, gula pasir, air mineral, natrium bikarbonat (NaHCO3), asam sitrat, dan asam malat.

Sirsak diblender dam saring untuk diambil sari sirsaknya, air kelapa saring dan dipanaskan hingga mencapai suhu $100{ }^{\circ} \mathrm{C}$, lalu didiamkan hingga suhu $80^{\circ} \mathrm{C}$. Sari sirsak dan air kelapa kemudian dicampurkan dengan perbandingan 80:20\% lalu ditambahkan gula dan asam sitrat kemudian dihomogenkan dengan cara diaduk. Setelah homogen cairan 
air kelapa dan ekstrak sirsak kemudian dimasukan ke dalam botol lalu dipasteurisasi pada suhu $80{ }^{\circ} \mathrm{C}$ selama 10 menit. Setelah panas, cairan tersebut didinginkan dengan air es dalam keadaan botol tertutup selama 3 menit. Kemudian ditambahkan Natrium Bikarbonat sebanyak $0,7 \quad \% \quad$ lalu dihomogenkan kembali dan disimpan pada suhu ruang.

\section{Jus Kurma Kelapa}

Jus adalah makanan cair yang dibuat dari sayuran dan atau buah-buahan dengan cara dihancurkan menggunakan blender. Jus kurma kelapa dapat mengurangi resiko anemia, karena kurma memiliki kandungan besi yang tinggi sedangkan air kelapa mengandung asam folat. Jus kurma juga berkhasiat untuk membantu proses penyembuhan berbagai penyakit. Hal tersebut karena jus mengandung berbagai zat mineral dan sari makanan yang telah terpisahkan dari seratnya sehingga mudah diserap oleh tubuh (Maria, 2008).

Jus kurma kelapa merupakan jus yang dibuat dari perpaduan buah kurma dan air kelapa. Pembuatan jus kurma sama seperti pembuatan jus pada umumnya yakni buah kurma dan air kelapa dimasukan ke dalam blender dan dihaluskan dengan perbandingan kurma 150 gram, air kelapa $250 \mathrm{ml}$ (Ilahi et al., 2019)

\section{Yogurt Kelapa}

Yoghurt selama ini dibuat dari susu dengan fermentasi menggunakan bakteri Lactobacillus acidophilus. Namun ternyata Lactobacillus acidophilus juga mampu mengubah senyawa yang terdapat di dalam buah kelapa menjadi asam laktat dan membentuk rasa asam seperti pada yogurt yang berasal dari susu.

Bahan untuk pembuatan yoghurt kelapa yaitu daging buah kelapa, air kelapa, beras pecah kulit (beras organik), dan air mineral. Beras cokelat organik sebanyak 20 gram direndam dengan air mineral $80 \mathrm{ml}$ dalam wadah kecil, daging buah kelapa sebanyak 500 gram dicampurkan dengan air kelapa sebanyak $50 \mathrm{ml}$ dan di-blender, kemudian campurkan liquid starter sebanyak $30 \mathrm{ml}$ dan diaduk dengan sendok kayu, dan difermentasi selama 24 jam pada suhu ruang $\left(20-30{ }^{\circ} \mathrm{C}\right)$ (Muharam, 2019).

\section{Drink Yoghurt}

Drink yoghurt merupakan produk diversifikasi dari yoghurt yang bertujuan untuk membuat produk yoghurt yang tidak terlalu asam, encer, dan mudah diminum. Pada penelitian Jannah et al. (2012) drink yoghurt dibuat dengan kombinasi susu encer dengan air kelapa. Air kelapa digunakan sebagai pengencer karena sebagian besar kandungannya berupa air. Air kelapa juga mengandung glukosa dan fruktosa yang merupakan monosakarida sehingga lebih mudah untuk dimanfatkan oleh bakteri asam laktat. Bahan yang digunakan yaitu susu segar encer, kultur stater bakteri asam laktat (L.bulgaricus dan S. thermophillus), dan air kelapa.

Cara pembuatan drink yoghurt adalah sebagai berikut: susu dikombinasikan dengan 
air kelapa $60 \%$ selanjutnya dipasteurisasi pada suhu $80 \quad{ }^{\circ} \mathrm{C}$ selama 15 menit, kemudian suhunya diturunkan hingga $3{ }^{\circ} \mathrm{C}$, setelah itu diinokulasikan dengan starter $3 \% \mathrm{v} / \mathrm{v}$, dan diinkubasi pada suhu $43{ }^{\circ} \mathrm{C}$ selama 4 jam, kemudian disimpan dalam refrigerator dengan suhu $5{ }^{\circ} \mathrm{C}$.

\section{Serbuk Minuman Kelapa}

Minuman serbuk kelapa merupakan produk serbuk hasil formulasi antara air kelapa dan daging kelapa muda yang dikeringkan menggunakan spray drying. Pembuatan produk serbuk minuman bertujuan untuk meningkatkan umur simpan dan memudahkan dalam distribusi produk.

Bahan yang digunakan pada penelitian Barlina et al. (2020) yaitu air kelapa tua, daging kelapa muda, dan maltodekstrin. Daging kelapa dan air kelapa dicampur kemudian di-blender dengan perbandingan $20 \%$ daging kelapa dan $80 \%$ air kelapa, selanjutnya ditambahkan maltodekstrin dan dikeringkan menggunakan alat spray dryer, kemudian dikemas.

\section{Minuman Probiotik}

Minuman probiotik adalah minuman yang difermentasi dengan bakteri asam laktat sehingga memberikan efek yang baik untuk pencernaan. Pada pembuatan minuman probiotik air kelapa muda digunakan bakteri Lactobacillus casei strain Shirota, dan gula pasir. Air kelapa muda dipasteurisasi pada suhu 700C selama kurang lebih 10 menit, kemudian dimasukkan ke dalam botol kaca steril dengan volume masing $100 \mathrm{ml}$ dan ditambahkan glukosa $0 \quad \%$ sambil dihomogenkan hingga suhu $31-32^{\circ} \mathrm{C}$. Kemudian diinokulasi dengan starter Lactobacillus casei strain Shirota sebanyak 3\% (b/v) dan dilakukan inkubasi pada suhu $37{ }^{\circ} \mathrm{C}$ selama 48 jam (Pranayanti dan Sutrisno, 2014).

Mandei et al. (2015) membuat minuman probiotik dengan menggunakan bahan lain yaitu air kelapa, wortel, gula pasir (sukrosa), susu skim, yakult, dan biokul plain. Air kelapa disaring dan dipasteurisasi pada suhu 80 ${ }^{\circ} \mathrm{C}$ selama 10 menit sedangkan wortel dipotong kecil-kecil kemudian diekstraksi untuk diambil sarinya menggunakan juice extractor. Air kelapa dan sari wortel dicampurkan dengan perbandingan 80:20. Setelah itu ditambahkan susu skim $1 \%$ dan gula sebanyak $10 \%$ (b/b) lalu dicampur hingga homogen. Campuran dipanaskan pada suhu $80{ }^{\circ} \mathrm{C}$ selama 10 menit. Setelah panas, campuran didinginkan hingga suhu $37^{\circ} \mathrm{C}$ lalu ditambahkan starter sebanayak $3 \%$ kemudian difermentasikan pada suhu 27 ${ }^{\circ} \mathrm{C}$ selama 24 jam.

\section{Sorbet Kelapa}

Sorbet merupakan makanan yang terbuat dari campuran buah segar dan pemanis yang dibekukan. Berdasarkan proses pembuatan dan teksturnya, sorbet hampir sama seperti es krim namun, dengan tekturnya lebih kasar, karena pada proses pembuatannya tidak digunakan emulsifier seperti telur dan gelatin (Sabtoningsih, 2012).

Agustina et al. (2016) membuat sorbet dari bahan air kelapa tua, pisang, CMC, asam sitrat 
dan gula pasir. Menurut Naomi et al. (2016) penggunaan air kelapa tua dalam pembuatan sorbet kelapa dapat mengurangi penggunaan gula karena air kelapa rasanya sudah cukup manis.

Pembuatannya sorbet air kelapa terdiri dari 2 tahap yaitu tahap pembuatan puree pisang dan tahap pembuatan sorbet. Tahap pembuatan puree pisang yaitu buah pisang direbus selama 1 jam kemudian dikupas, dicuci dan dipotong kecil-kecil, selanjutnya di-blender hingga halus. Tahap pembuatan sorbet yakni air kelapa dipanaskan pada suhu $50{ }^{\circ} \mathrm{C}$, lalu dicampurkan dengan bahan-bahan lain. Pembuatan sorbet menggunakan komposisi puree pisang 150 gram, air kelapa $350 \mathrm{ml}$, gula 50 gram, asam sitrat 1 gram dan CMC 1 gram. Semua bahan tersebut dicampur dan dipanaskan hingga suhu maksimum $70{ }^{\circ} \mathrm{C}$. Setelah itu pemanasan dihentikan, kemudian didinginkan dan dilakukan pembekuan selama satu hari. Campuran yang telah beku di-mixer dan dilakukan pengemasan. Selanjutnya dilakukan pembekuan kembali selama satu hari (Agustina et al., 2016).

\section{Edible Film}

Edible film yaitu lapisan tipis yang dapat dikonsumsi dan dapat dijadikan sebagai penghalang kelembaban oksigen dan gas (Dedin Finatsiyatull Rosida, 2018). Edibel film ini dapat langsung dikonsumsi bersamaan dengan produk yang dikemas sehingga dapat mengurangi pencemaran lingkungan.

Pada pembuatan edible film, air kelapa diolah menjadi bioselulosa. Pembuatan bioselulosa ini dibuat menggunakan air kelapa segar yang difermentasi dengan Acetobacter xylinum. Lama fermentasi sama dengan fermentasi nata de coco pada umumnya. Bahan yang digunakan yaitu air kelapa matang, sakarosa, asam asetat teknis, dan biakan murni Acetobacter xylinum. Air kelapa segar disaring dan dibiarkan selama 4 hari, kemudian dipanaskan sampai mendidih, ditambahkan gula pasir dan kultur Acetobacter xylinum kemudian difermentasi selama 14 hari (Barlina et al., 2016). Bioselulosa yang dihasilkan dapat dipakai sebagai bahan baku pembuatan edible film.

\section{Coco Cider}

Cider merupakan minuman dengan kadar alkohol rendah $(6,5-8 \%)$ yang dibuat dari fermentasi sari buah atau bahan lain yang mengandung pati. Di Amerika, cider dibuat dari buah jus apel yag tidak difermentasi. Menurut Aditiwati dan Kusnadi (2003) cider yang sudah dikenal di Indonesia adalah cider dari teh. Produk ini merupakan hasil fermentasi larutan teh dan gula menggunakan stater mikroba (Acetobacter xylium, Saccharomyces cereviseae, Candida sp dan Hansenulla sp).

Air kelapa dapat dibuat menjadi cider. Menurut Wrasiati et al. (2013) bahan yang digunakan dalam pembuatan cider adalah air kelapa, gula pasir, starter cider, alkohol. Air kelapa ditambahkan gula $10 \%$, dipanaskan selama 5 menit, lalu didinginkan pada suhu kamar. Setelah dingin dimasukan ke dalam botol kaca yang sudah disterilisasi dan 
dipasteurisasi pada suhu $82{ }^{\circ} \mathrm{C}$ selama 30 menit lalu didinginkan kembali. Setelah dingin, diinokulasi dengan starter coco cider dan diinkubasi selama 2 hari pada suhu $27^{\circ} \mathrm{C}$. Kefir

Kefir merupakan minuman yang dihasilkan dari fermentasi susu dengan kultur mikroorganisme (Jaya, 2019). Kefir dan yoghurt hampir sama karena pada proses pembuatannya sama-sama menggunakan suatu kultur mikroorganisme yang diinokulasi pada susu namun berbeda pada jenis mikroorganisme yang digunakan. Yoghurt hanya terdiri dari strain Lactobacclilus dan Streptococcus, sedangkan kefir difermentasi dengan mikroba Lactoccilus, Leuconostoc, Acetobacter, Streptococus, dan Pseudomunas spp. Kefir memiliki rasa yang yang lebih asam dari yoghurt karena dibuat dari bakteri asam laktat.

Kefir juga dapat dibuat dari bahan dasar berupa cairan yang mengandung gula seperti sari buah, air kelapa, dan air gula. Pada penelitian Lestari et al. (2018) air kelapa digunakan sebagai bahan utama pengganti susu pada pembuatan kefir.

Cara pembuatannya yaitu air dipasteurisasi pada suhu $60^{\circ} \mathrm{C}$ selama 30 detik, lalu didiamkan hingga suhu menjadi $28^{\circ} \mathrm{C}$. Setelah itu ditambahkan butir kefir sebanyak 5\% lalu difermentasi selama 24 jam.

\section{Susu Kelapa}

Susu kelapa merupakan susu fermentasi yang dibuat dari santan kelapa dan air kelapa dengan bantuan kultur kerja Lactobacillus casei yang difermentasi secara anaerob. Susu kelapa sebagai susu nabati dapat menjadi alternatif bagi penderita lactose intolerant.

Bahan yang digunakan pada pembuatan susu kelapa yaitu daging buah kelapa setengah tua, ubi jalar, air kelapa hijau, air mineral, gula, garam, MRS Agar dan Broth, susu skim, pektin, alkohol 70\%, dan kultur bakteri asam laktat (Lactobacillus casei) (Kurniati, 2010).

Proses pembuatan susu kelapa dilakukan dengan cara: daging kelapa dikupas dan diblanching dengan suhu $80{ }^{\circ} \mathrm{C}$ selama 5 menit kemudian diekstrak menggunakan blender juicer. Hasil ekstrak kelapa tersebut ditambahkan air kelapa lalu dihomogenkan selanjutnya disaring. Filtrat dari penyaringan ditambahkan pektin $1 \%$ (b/v), kemudian dihomogenisasi kembali. Campuran ini kemudian dipasteurisasi menggunakan microwave dengan suhu $85^{\circ} \mathrm{C}$ selama 1 menit kemudian didinginkan. Setelah dingin, susu kelapa diinokulasi dengan kultur kerja Lactobacillus casei sebanyak 2\% (v/v) dan ditambahkan sari ubi jalar, diinkubasi selama 24 jam pada suhu $37{ }^{\circ} \mathrm{C}$. Setelah terbentuk larutan susu kelapa, selanjutnya dihomogenisasi dan disimpan pada suhu $4{ }^{\circ} \mathrm{C}$ (Kurniati, 2010).

\section{Anggur}

Anggur adalah minuman beralkohol berasal dari sari buah anggur yang difermentasi (Pawignya et al., 2010). Air kelapa dapat diolah menjadi anggur kelapa menggunakan cara fermentasi starter mikroba yang 
mengandung khamir (S. cerevisiae dan $S$. Ellipsoides).

Bahan yang digunakan yaitu air kelapa sebagai bahan, kultur murni S. cerevisiae dan S. ellipsoides. Menurut Karouw (2018) cara pembuatan anggur kelapa dibagi menjadi 2 tahap yakni tahap persiapan starter dan tahap pembuatan anggur air kelapa. Tahap persiapan starter yaitu air kelapa disaring dan dipasteurisasi pada suhu $60{ }^{\circ} \mathrm{C}$ selama 30 menit lalu didinginkan. Kemudian diinokulasi dengan kultur murni $S$. cerevisiae dan $S$. ellipsoids. Tahap pembuatan anggur meliputi penyaringan air kelapa dan penambahan gula pasir 1 gram untuk setiap liter air kelapa. Larutan dipasteurisasi pada suhu $60{ }^{\circ} \mathrm{C}$ selama 30 menit, didinginkan, dimasukan ke dalam botol fermentasi dan ditambahkan starter mikroba.

\section{Kecap}

Kecap adalah larutan berwarna coklat sampai hitam, berasa manis atau asin dan digunakan sebagai bumbu masak. Kecap sering kali digunakan pada makanan supaya lebih nikmat, misalnya pada sate, ayam kecap, ikan bakar dan lain-lain. Pada umumnya kecap dibuat bahan yang mengandung protein tinggi seperti kacang-kacangan.

Menurut Farapti (2014) air kelapa sangat potensial dijadikan bahan baku pembuatan kecap. Pada penelitian Kusumawardani (2011) air kelapa dijadikan sebagai bahan baku pengganti kacang kedelai. Bahan utama yang digunakan yaitu air kelapa dan gula merah 800 gram, sedangkan bahan tambahan berupa bubuk tempe 200 gram, wijen 20 gram, kemiri 20 gram, bawang putih 30 gram, laos 40 gram, daun jeruk purut 7 lembar, daun salam kering 4 lembar, sereh segar 4 batang dan garam.

Pembuatannya adalah sebagai berikut: tempe dihaluskan hingga berbentuk serbuk kemudian diayak, wijen disangrai kemudian dihaluskan bersama keluwak kemiri, dan gula merah yang sebelumnya telah diiris supaya mudah dilarutkan. Setelah semua bahan tersebut dicampurkan dengan air kelapa kemudian dipanaskan selama 2 jam. Setelah 2 jam, larutan kecap disaring untuk memisahkan bubuk tempe, sereh dan daun salam serta laos yang tidak larut. Kecap yang sudah jadi kemudian dikemas.

\section{Permen Kelapa Jahe}

Permen merupakan produk yang menyenangkan untuk dikonsumsi dan disukai oleh semua kalangan. Jarang orang mengonsumsi permen dengan tujuan untuk memperoleh zat gizi tertentu. Umumnya orang mengonsumsi karena menyukai rasa permen tersebut, oleh karena itu permen sering disebut sebagai fun food.

Permen kelapa jahe merupakan permen yang dibuat dari campuran santan kelapa dan sari jahe. Pada pembuatan permen kelapa jahe ini, air kelapa digunakan untuk menambah jumlah cairan santan pada saat pemerasan. Menurut Jurait dan Mardesci (2016) penggunaan air kelapa dalam pembuatan permen kelapa dapat meningkatkan kadar air, kadar gula, dan tingkat keasaman permen. 
Bahan utama yang digunakan pada penelitian Robot et al. (2020) adalah sari jahe $4 \%$, santan kelapa $100 \mathrm{ml}$, sukrosa 20\%, gula aren $80 \%$. Sebanyak $100 \mathrm{ml}$ santan ditambahkan gula aren $80 \%$ dan sukrosa $20 \%$, kemudian dipanaskan sambil diaduk sampai mendidih. Setelah itu disaring dan dipanaskan kembali, lalu ditambahkan $4 \%$ sari jahe dan diaduk selama 10 menit hingga adonan berwarna cokelat. Adonan dicetak dan dibiarkan mengeras kemudian dikemas.

\section{Permen Jelly Kelapa}

Jelly pada umumnya dibuat dari sejenis umbi konyaku yang kaya serat namun rendah kalori. Jelly biasanya digunakan sebagai makanan untuk diet alami. Karakteristik jelly yaitu lebih lembut, lentur, dan lebih kenyal dibanding agar-agar (Susanto, 2014). Pada penelitian Novitasari (2013), permen jelly dibuat dari kulit semangka dengan penambahan pemanis daun stevia dan air kelapa muda. Menurut Meieri Adelia et al. (2017) cara pembuatan permen jelly kelapa yaitu kulit semangka dibersihkan kemudian diblender hingga terbentuk puree, kemudian disaring untuk diperoleh ekstraknya. Ekstrak tersebut dicampur dengan air kelapa kemudian direbus pada suhu $70^{\circ} \mathrm{C}$ selama 5 menit. Setelah itu, ditambahkan karagenan dan gula stevia, dipanaskan sambil diaduk hingga mengental, ditambahkan asam sitrat, dituang ke dalam loyang dan ditutup dengan alumunium foil dan dibiarkan selama 1 jam. Setelah itu dimasukan ke dalam refrigerator pada suhu $5^{\circ} \mathrm{C}$ selama 24 jam.

\section{Keju Kelapa}

Keju merupakan produk susu yang diperoleh dari proses penggumpalan susu dan pemisahan whey dari susu (Purwadi, 2019). Selain dibuat dari susu, keju ternyata dapat dibuat dari bahan nabati, yang berupa blondo putih hasil samping pengolahan VCO. Pada penelitian Sukendar et al. (2019) bahan utama yang digunakan dalam pembuatan keju kelapa adalah blondo putih, air kelapa, air mineral, laktosa, STPP, perwarna makanan, pengawet asam propinate, dan tapioka.

Pembuatan keju kelapa terdiri dari 3 tahap yakni preparasi blondo putih, fermentasi blondo, dan pencampuran blondo fermentasi dengan gel tapioka. Pada tahap preparasi blondo, krim santan kelapa yang telah diperolah dimasak untuk memisahkan minyak dan blondo. Proses pemasakan dihentikan apabila blondo putih sudah memadat dan berwarna cokelat mudah. Blondo ini kemudian dipisahkan dari minyaknya. Tahap fermentasi blondo adalah sebagai berikut: sebanyak 250 gr blondo dihaluskan dan dicampur dengan inokulum spontan sebanyak $200 \mathrm{ml}$, glukosa $1,5 \%$ Campuran tersebut kemudian ditambahkan air kelapa segar sebanyak 45 $\mathrm{m}^{* * 1}$, kemudian diperam pada suhu ruang selama 3 hari secara anaerob. Adapun tahap pencampuran blondo fermentasi dan gel tapioka adalah dengan cara: blondo yang telah difermentasi dicampur dengan gel tapioka (1:1), garamNaCl $2 \%$, pewarna annato $1 \%$, dan pengawet asam propinat. Pencampuran dilakukan dengan hand mixer hingga 
dihasilkan adonan keju. Adonan keju kemudian dituangkan ke dalam alumunium foil lalu diperam pada suhu kamar selama 72 jam. Keju kelapa yang sudah jadi disimpan dalam kulkas.

\section{Selai Kelapa}

Selai adalah produk makanan dengan konsisten gel atau semi padat yang dibuat dari campuran gula, buah, dan pektin. Menurut Arsyad (2018) air kelapa dan daging kelapa muda dapat diolah menjadi selai.

Bahan yang digunakan adalah daging kelapa dan air kelapa muda, gula pasir, serta pektin. Daging kelapa 300gram, air kelapa 150 ml, dan gula 300 gram, kemudian air daging kelapa dan air kelapa dihaluskan dengan blender hingga terbentuk puree. Selanjutnya proses pelarutan gula menggunakan air mineral 300 ml. Larutan kemudian ditambahkan ke dalam puree kelapa bersama dengan pektin 1 gram. Langkah selanjutnya adalah pemasakan di dalam panci, sambil diaduk secara perlahan menggunakan api yang kecil. Selai didinginkan dan dimasukkan ke dalam kemasan.

\section{KESIMPULAN}

Air kelapa merupakan sumber bahan baku pangan yang bernilai gizi tinggi. Diversifikasi produk air kelapa dapat berupa air kelapa kemasan, minuman isotonik, nata de coco, cuka, minuman antioksidan, minuman berkarbonasi, jus kurma, yoghurt kelapa, drink yoghurt, serbuk minuman kelapa, minuman probiotik, sorbet kelapa, edible film, coco cider, kefir, susu kelapa, kecap, permen kelapa jahe, permen jelly kelapa, keju kelapa, dan selai kelapa.

\section{DAFTAR PUSTAKA}

Adelia, M., Setiaies, V. dan Pato, U. 2017. Pengaruh Penambahan Kelopak Rosella terhadap Mutu Sensori Permen Jelly dari Albedo Semangka. Jurnal Online Mahasiswa Fakultas Pertanian Universitas Riau. 4 (1): 1-12.

Aditiwati, P. dan Kusnadi, K. 2003. Kultur Campuran dan Faktor Lingkungan Mikroorganisme yang Berperan dalam Fermentasi "Tea-Cider". Journal of Mathematical and Fundamental Sciences. 35 (2): 147-162.

Agustina, Y., Achyadi, N. S. dan Arief, D. Z. 2016. Kajian Korelasi Suhu Pasteurisasi Dan Perbandingan Ekstrak Rosella (Hibiscus Sabdariffa) Dengan Air Kelapa (Cocos Nucifera) Terhadap Intensitas Warna Dan Antioksidan Menggunakan Analisis Regresi Linier. Skripsi. Fakultas Teknik, Universitas Pasundan, Bandung.

Arsyad, M. 2018. Pengaruh Konsentrasi Gula Terhadap Pembuatan Selai Kelapa Muda (Cocos nucifera L). Gorontalo Agriculture Technology Journal. 1 (2): 35-45.

Barlina, R. 2016. Potensi buah kelapa muda untuk kesehatan dan pengolahannya. Perspektif. 3 (2): 46-60.

Barlina, R., Kapu'allo, M. dan Goniwala, E. 2016. Pengaruh lama penundaan dan inkubasi air kelapa terhadap karakteristik bioselulosa untuk bahan baku edible film. Buletin Palma. 15 (2): 134-140.

Barlina, R., Karouw, S., Hutapea, R. dan Towaha, J. 2020. Pengaruh Perbandingan Air Kelapa dan Penambahan Daging Kelapa Muda serta Lama Penyimpanan terhadap Serbuk Minuman Kelapa. Jurnal Penelitian Tanaman Industri. 13 (2): 73-80.

Dedin Finatsiyatull Rosida, N. H., Retno Dewati 2018. Edible Coating dari Biopolimer Bahan Alami Terbarukan Uwais Inspirasi Indonesia, Ponorogo.

Farapti, S. S. 2014. Air kelapa mudapengaruhnya terhadap tekanan darah. Continuing Professional Development. 41 (12): 896-900.

Hamad, A. dan Kristiono. 2013. Pengaruh Penambahan Sumber Nitrogen Terhadap Hasil 
Fermentasi Nata de Coco. Majalah Ilmiah Momentum. 9 (1): 62-65.

Hasanuddin, Kurnia Harlina Dewi dan Wulandra, O. 2012. Penggunaan Air Kelapa Untuk Bahan Dasar Cuka Makan. Jurnal Agroindustri. 2 (2): $1-11$.

Ilahi, K., Susyani, S. dan Terati, T. 2019. Pemberian Jus Kurlapa Dalam Meningkatkan Kadar Hemoglobin Pada Remaja Putri Yang Anemia Di Ma AlMu'aawanahogan Ilir. Jurnal Kesehatan Poltekkes Palembang. 14 (1): 13-17.

Jannah, Nurwantoro dan Pramono. 2012. Kombinasi Susu dengan Air Kelapa pada Proses Pembuatan Drink Yogurt terhadap Kadar Bahan Kering, Kekentalan dan $\mathrm{pH}$. Jurnal Aplikasi Teknologi Pangan. 1 (3): 69-71.

Jaya, F. 2019. Ilmu, Teknologi Dan Manfaat Kefir. UB Press, Malang.

Jurait, M. dan Mardesci, H. 2016. Studi Pembuatan Permen Dari Air Kelapa Terhadap Karakteristik Dan Penerimaan Konsumen. Jurnal Teknologi Pertanian. 5 (1): 23-29.

Kailaku, Intan, S., Budi, S. dan Ahmad, S. 2016. Pengaruh Proses Membran Ultrafiltrasi Dan Ultraviolet terhadap Komposisi Gizi, Sifat Fisikokimia dan Organoleptik Minuman Air Kelapa. Jurnal Littri. 22 (43): 43-51.

Karouw, S. 2018. Pengolahan Anggur Berbasis Air Kelapa. Buletin Palma. (33): 60-66.

Kurniati, Y. 2010. Kajian Penambahan Sari Ubi Jalar Sebagai Sumber Prebiotik Pada Susu Kelapa yang Difermentasi oleh Lactobacillus Casei Fncc 0090. Skripsi. Universitas Lampung, Fakultas Pertanian, Lampung.

Kusumawardani, W. 2011. Proses Produksi Pemanfatatn Air Kelapa Sebagai Produk Olaha Kecap dengan Penambahan Bubuk Kedelai dan Bubuk Tempe. Skripsi. Fakultas Pertanian, Universitas Sebelas Maret,

Lestari, M. W., Bintoro, V. P. dan Rizqiati, H. 2018. Pengaruh Lama Fermentasi terhadap Tingkat Keasaman, Viskositas, Kadar Alkohol, dan Mutu Hedonik Kefir Air Kelapa. Jurnal Teknologi Pangan. 2 (1): 8-13.

Lestario, L. N. 2017. Antioksidan: Sifat Kimia, Peranannya Dalam Kesehatan Dan Prospeknya Sebagai Pewarna Makanan. Universitas Gajah Mada, Yogyakarta.

Mandei, J. H., Edam, M. dan Assah, Y. F. 2015. Rasio Campuran Air Kelapa Sari Wortel dan Variasi Susu Skim Terhadap Mutu Minuman Probiotik. Jurnal Riset Teknologi Industri. 3 (2): 192-205.

Maria, A. 2008. Bertahan Hidup dengan Terapi Jus. Pustaka Anggrek, Yogyakarta.
Marlina, S., Mustafir,Saleha S, Ahmi F,Murniana,Khairan. 2017. Sintesis Membran Poliuretan Berbasis Bahan Alam. Universitas Syiah Kuala Press, Banda Aceh.

Meieri Adelia, Setiaies, V. dan Pato, U. 2017. Pengaruh Penambahan Kelopak Rosella terhadap Mutu Sensori Permen Jelly dari Albedo Semangka. Jurnal Online Mahasiswa Fakultas Pertanian Universitas Riau. 4 (1): 1-12.

Muharam, T. 2019. Pembuatan Yogurt Vegan Dari Daging Buah Kelapa. Skripsi. Manajemen Tataboga, Sekolah Tinggi Pariwisata Bandung.

Naomi, B. C., Herla, R. dan Lasma , N. L. 2016. Pengaruh Perbandingan Sari Labu Kuning Dengan Sari Nenas dan Penambahan Gelatin terhadap Mutu Sorbet Air Kelapa. Junal Rekayasa Pangan dan Pertanian. 4 (4): 500507.

Ndaru, K. 2008. Khasiat Cuka Cairan Alami Penyembuh Alami. PT MIzan Publika, Jakarta Selatan.

Novitasari, B. A. 2013. Uji Vitamin C Dan Organoleptik Permen Jelly Dari Pemanfaatan Kulit Semangka Dengan Penambahan Air Kelapa Muda Dan Daun Stevia Sebagai Pemanis. keguruan dan Ilmu Pendidikan, Universitas Muhammadiyah Surakarta, Surakarta.

Pawignya, H., Widayati, T. W., Putra, D. dan Akbar, P. Tinjauan Kinetika Pembuatan Rose Wine. Pengembangan Teknologi Kimia Untuk Pengolahan Sumberdaya Alam Indonesia. 26 Januari. 2010, Yogyakarta.

Pranayanti, I. a. P. dan Sutrisno, A. 2014. Pembuatan Minuman Probiotik Air Kelapa Muda (Cocos Nucifera L.) Dengan Starter Lactobacillus Casei Strain Shirota. Jurnal Pangan Dan Agroindustri. 3 (2): 763-772.

Purwadi. 2019. Ilmu Dan Teknologi Pengolahan Keju. UB Press, Malang.

Robot, R., Ludong, M. dan Mamuaya, C. 2020. Pengaruh Konsentrasi Sari Jahe Merah (Zingiber officinale var. Rubrum) Terhadap Hasil Uji Sensoris Permen Kelapa Jahe. Cocos. 1 (2): 1-10.

Saat, M., Singh, R., Sirisinghe, R. G. dan Nawawi, M. 2002. Rehydration after exercise with fresh young coconut water, carbohydrate-electrolyte beverage and plain water. Journal of physiological anthropology and applied human science. 21 (2): 93-104.

Sabtoningsih, J. A. 2012. Membuat Olahan Buah. PT. Agromedia Pustaka, Jakarta selatan. 
Sukendar, N., Ihsan, Z. dan Langkung, Z. 2018. Studi Pembuatan Minuman Isotonik Berbahan Baku Air Kelapa Tua (Cocos Nicifera L) Dan Ekstrak Belimbing Wuluh (Avverhoa Bilimbi L) Menggunakan Metode Sterilisasi Non-Thermal Selama Penyimpanan. Jurnal Food Technology, Nutritions, and Culinary. 1 (1): 5362.

Sukendar, N. K., Syarifuddin, A., Djalal, M., Chadijah, A. Y. dan Hidayat, S. H. 2019. Studi Pembuatan Keju Kelapa. Prosiding Seminar Nasional Inovasi Teknologi Hasil Perkebunan. 1 (1): 152-158.

Susanto, S. 2014. Mudah Membuat Jelly Art. Demedia Pustaka, Jakarta Selatan.

Winarsih, H. 2007. Anti Oksidan Alami dan Radikal Bebas Kanisius, Yogyakarta.

Wrasiati, L. P., Arnata, I. W., Yoga, I. W. G. S. dan Wijaya, I. M. M. 2013. Pemanfaatan Limbah Air Kelapa Menjadi Produk Coco Cider: Kajian Penambahan Gula dan Waktu Fermentasi. Bumi Lestari Journal of Environment. 13 (1): 106114.

Yong, J. W., Ge, L., Ng, Y. F. dan Tan, S. N. 2009. The chemical composition and biological properties of coconut (Cocos nucifera L.) water. Molecules. 14 (12): 5144-5164.

Zulaika, N., Suhaidi, I. dan Lora, L. L. 2016. Pengaruh Perbandingan Air Kelapa Tua Dengan Sari Sirsak dan Konsentrasi Natrium Bikarbonat (NaHCO3) Terhadap Mutu Minuman Air Kelapa Berkarbonasi. Jurnal Rekayasa Pangan dan Pertanian. 4 (4): 517524. 